\title{
DIVERSIFICATION OF ECONOMY - AN INSIGHT INTO ECONOMIC DEVELOPMENT WITH SPECIAL REFERENCE TO KURDISTAN'S OIL ECONOMY AND AGRICULTURE ECONOMY
}

\author{
Pankaj Dixit ${ }^{*}$, Assistant Professor \\ Department of Accounting and Finance, Lebanese French University, Erbil, Kurdistan \\ Dr. Ramyr Rzgar, Assistant Professor and Dean \\ College of Business and Economics, Lebanese French University, Erbil, Kurdistan \\ *E-mail: pdixit2989@gmail.com
}

\begin{abstract}
Diversifying economy from one sector to another is a vital problem faced by many nations across the globe. Many countries believe that economic development is achieved by diversifying the economy by switching the major revenue sectors. The main objective of this research paper is to study the economic development of Kurdistan region through diversification from Oil to agriculture economy and one more objective is to find out how the role of FDI will create the impact over the growth of economy in agriculture sector. The study is concentrated on 50 agriculturists through convenience sampling method. Kurdistan is an autonomous province in Iraq which is heavily dependent on oil sector for its major part of revenue. On the other hand it is ignoring agriculture sector which has a great potential to earn heavy revenue for the country. This paper reveals that, the Agriculture can play the major role in the economic development of Kurdistan in future as an employment generation, increase in GDP, Increase in Government revenue and diversify development. This research paper proposes some financial model for the possible growth of agriculture sector along with agro technology through small investor FDI scheme and Agriculture insurance scheme. From this study, it is found that if proposed suggestion is been concentrated on agriculture by KRG surely GDP will increase.
\end{abstract}

\section{KEY WORDS}

Diversification, economic development, agriculture, economy, insurance.

The Kurdistan Region includes parts of the three governorates of Erbil, Sulemani and Duhok. It fringes Syria toward the west, Iran toward the east, and Turkey toward the north, lying where fruitful fields meet the Zagros Mountains. It is navigated by the Sirwan River and the Tigris and its tributaries. The mountains of the Kurdistan Region have a normal stature of around 2,400 meters, ascending to 3,000-3,300 meters in spots. The most noteworthy pinnacle, Halgurd, is close to the outskirt with Iran and measures 3,660 meters. The most elevated mountain edges contain the main forestland in the Region. The climate of the Kurdistan is favorable for agriculture. This area has the 5 river for irrigation and the varied topography and associated rainfall regimes have created three basic micro-climatic zones; high rainfall $(700-1100 \mathrm{~mm})$, medium rainfall $(400-700 \mathrm{~mm})$, and low rainfall (under $400 \mathrm{~mm}$ ). In terms of produce; the high-rainfall zone contains mainly fruit orchards, wheat occupies most of the medium-rainfall zone, and barley is the main crop in the low-rainfall zone. Winter wheat and barley are planted in the autumn (October-November) and harvested in the late spring (April-June) in accordance with the rainfall pattern. Financing remains a thistle in the side of those gatherings looking to additionally create horticulture in Kurdistan, especially since the Region keeps on depending on a lot of imported nourishment items. Without a doubt, a few evaluations have put figures for this utilization in the area of \$20-22 billion for the entire of Iraq. In this manner, reserves that could be better spent on ventures are rather spent on imports to fulfill expanding request [1]. 


\section{LITERATURE REVIEW}

Baban, S. (2015) "Revitalizing Agriculture and Water Sectors in the Kurdistan Region, Iraq" has stated in his paper about the progress of the implementation of a specifically developed road map June 2012- May 2014, aimed to achieve food sufficiency and security for the region. The road map provided a way forward to rehabilitate and improve the agriculture sector based on a vision that introduces effective modern production, training, management and reflective systems for sustainable agriculture and food production in the region [2].

Lina Eklund, Abdulhakim Abdi and Mine Islar (2017) "From Producers to Consumers: The Challenges and Opportunities of Agricultural Development in Iraqi Kurdistan" has stated in his paper about the agricultural situation in Iraqi Kurdistan from three perspectives, the biophysical, the political, and the socio-economic. He has highlighted that locals have strong ties to their lands and traditional agricultural practices are still prevalent. In this context, supporting small-scale traditional agriculture development might be more sustainable and feasible. Practices of small-scale agriculture in self-rule communities can serve as an alternative model to top-down large-scale agriculture as aspired by the KRG. In order to overcome the current and future problems of food scarcity, communities, like Rojava in Syrian Kurdistan, have started their own agricultural plan based on permaculture farming and participatory principles [3].

Abdulmuttaleb Abbas Salih, Hussein Ali Hussein Al-Qaesi (2018) "The perspective of agricultural development in Iraq": from this study we find that Iraq, and also the countries that were taken into study have developed a solution to one of the most important problems - the irrigation area. As it could be seen, all the countries have increased the surfaces equipped for irrigation, doubling or tripling it. Extension and counseling help farmers to make the best decision for the agriculture development. Extension organizations need to develop communication with fertilizer providers since excessive use of agrochemicals can harm human health and the environment, and programs such as integrated pest management are recommended [4].

Objective of the study:

- To study the economic development through agriculture in Kurdistan region;

- To study the development of Kurdistan region through diversification from Oil to agriculture economy;

- To study how the economy diversification can generate the employment opportunities;

- To study the role of FDI in agriculture sector for improvements.

\section{METHODS OF RESEARCH}

The present study is agriculture oriented pertaining to economic development in Kurdistan region. This study is based on the survey method using structure of questionnaire. The results were found by using percentage analysis method.

Data Collection:

- Primary Data: For collection of data, the researcher used a structure questionnaire data. This was distributed to 50 respondents across the study area;

- Secondary Data: The secondary data been gathered from internet, Journals, reports, Government offices.

\section{RESULTS AND DISCUSSION}

The Economy of Kurdistan can be divided into three sectors:

Primary sector: Crude oil is the primary source of income of this region; this sector contributes approximately $80 \%$ of the GDP of this region, which is the main source of government's income. But this sector is depending upon the central government policies. Even the volatility in the prices of crude oil can affect the revenue of this sector. 
Secondary sector: Agriculture is assuming the second significant job in the Kurdistan economy. As of now this division contributes roughly $10 \%$ of GDP of this district. This speaks to a low commitment, and implies that assets are in adequately differentiated in the KRG. In this regard, decrease in the agrarian area adverse affected the economy. The agribusiness segment in the Kurdistan Region has seen significant change as of late and in this way can possibly assume a noticeable job in supporting the development of the neighborhood economy.

Tertiary Sector: It includes tourism, Industry, Real estate, Services and others. This sector is divided in major sub-sectors of business, but yet these sub-sectors are running in crocodile speed way of development. These sub-sectors of Kurdistan's economy needs more infrastructural requirement so they can play the crucial role in the area of development.

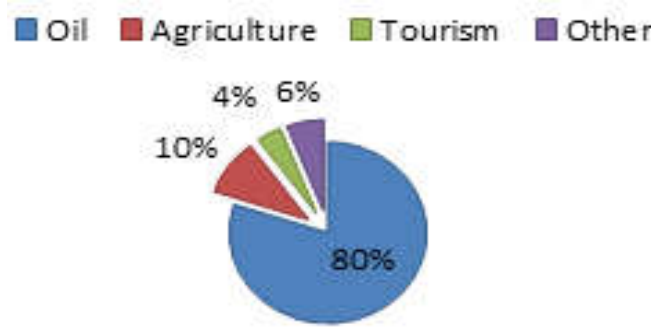

Figure 1 - Kurdistan's GDP sector-wise data (Source: invest in group 2013)

Diversification of Kurdistan's Economy. Diversification Economy = Developing non-oil segments and bringing down oil money related reliance (i.e., Export diversification, government income, and financial base); and making a feasible non-oil present day economy (Agriculture economy) that can support a moderately abnormal state of salary [5].

Importance of Diversification for Kurdistan. Oil part isn't making adequate occupations specifically. Oil costs/income change broadly, oil dispersion can't bolster rising expectations for everyday comforts. Flimsiness of oil income affects the general development rates (basically through changes in government spending), monetary and outer position, and business.

\section{Another Relevance of Diversification:}

- To lessen or minimize the spread risk;

- To advance monetary improvement;

- To constrain the effect of vacillations in the oil cost and amount created;

- To make openings for work for a quickly developing neighborhood work drive.

As of late Kurdistan is experiencing money related emergency, Apart from monetary emergency, Global oil costs have fallen by more than 50 percent since mid-2014. This comprises a noteworthy hit to the Iraqi and Kurdistan Regional Government (KRG) treasuries as oil rents represent more than 90 percent of state salary. Then again, weights on the Iraqi treasury have expanded enormously because of the expenses related with indicting the war against the Islamic State of Iraq and the Levant (ISIL), statistic weights from inside uprooted individuals (IDPs) and outcasts, and an enlarged open segment. To put it plainly, both Iraq and the KRG are unequipped for adjusting their financial plans. Today individuals endure because of remiss approaches and the uncontrolled spending of the previous decade. To address this, the Iraqi bureaucratic and Kurdish local governments require a mix of both transient answers for manage the quick fall in income and longer term auxiliary changes so as to plan for the following blast and bust cycle.

The greater parts of individuals in the Kurdistan Region are monetarily reliant on the administration, which is itself subject to oil salary. In the same way as other oil-based economies, the area's monetary blasts and busts are vigorously affected by the oil part. In view of this system, where is the Kurdistan region economy heading within a reasonable time-frame? Open Sector On one hand, adjusting incomes and costs for the Kurdistan Regional Government (KRG) is subject to oil costs and the rate of fare. On the other, it is controlled by open spending and the rate of getting. Despite the fact that the KRG's ability to 
send out oil will step by step increment, it has no influence over the worldwide cost of unrefined, while the lift in oil creation won't really convert into essentially better monetary conditions throughout the following couple of years.

The KRG's open borrowings of more than $\$ 15$ billion are higher than its yearly salary and these have not been spent on gainful ventures. The greater part of the KRG's financial plan is designated to paying $\$ 700$ million worth of month to month pay rates. The quantity of open workers is evaluated to be an uncommon 1,350,000. The facts confirm that these pay rates animate interest for products and ventures, empowering regular business in the district. In any case, inefficient open uses basically infuse more money into the economy, expanding inflationary weights on imported buyer products. Neighborhood creation is barely helped by this pattern. Merchandise and enterprises created in the Kurdistan area can barely rival better, less expensive imported remote items and administrations.

This is notable, Before 2003 Kurdistan was prosperous through its agriculture sector. Now the dependency of oil sector should be diversified in agriculture so that government budget insufficiency can be compensated and the people dependency on government's budget can be diversified in agriculture sector.

Challenges in Diversification. The non-oil sector was obliged by extremely constrained agrarian innovation and local work, absence of qualified labor, high lack of education rate, and a moderately little market measure. The test of financial diversification for asset rich nations is troublesome and disputable, notwithstanding for a nation standing up to this test during an era of kind household and local security conditions. For Iraq, distressed by fear mongering at home, overflows from local clash, the inheritance of war and endorses, and political vulnerability, the test is exponentially progressively significant. This note recommends that notwithstanding the overwhelming obstructions, Iraq can and should plan and dispatch an expansion procedure containing clear approach needs for activity over a 3 to multi year time frame. Obviously, this technique will assume that correlative moves are being made in related spaces to enhance resident security, give equity, and make employments the three mainstays of the harmony building standards illustrated in the World Development Report (WDR) 2011 [6].

Potential for becoming economic developed area in the Middle East region (Agriculture Economy). Kurdistan is a region of immense potential. This district is brimming with numerous regular assets in the Middle East and additionally this region has been shielded from the difficulties of psychological oppression as a result of Kurds' convictions in harmony. There is colossal potential for monetary improvement in this little area which can leave the nations like Dubai and Oman, as well.

In terms of natural resources, this small province is more financially richer than other areas of Iraq. Even, when the entire Middle East region was suffering from the outbreak of terrorism during 2014 , at that time it was able to keep itself stable by fighting the challenges of terrorism. The security forces of this province played an important role in eradicating ISIS in collaboration with the Iraqi army, which has led to confidence in the stability of the province in the international community. In spite of immense potential, this sector has been backward in economic strategies, which has a dispute with the federal government. If this autonomous province will resolves its internal disputes through dialogue with the federal government and do more focus on implementation of relevant economic strategies, Then It can be a best economy growth example for all.

For the future, the Region can called as the "Green place that is known for Iraq and Middle East" A phenomenal variety of grains and vegetables have characteristic been created in Kurdistan, with wheat and grain among the most notable. Regardless, in light of the methodologies of the Past daily schedule in Baghdad, agriculture in the Kurdistan Region was confined for improvement. In spite of the way that the agriculturists working in the Kurdistan Region have essential experience, they have been confined with respect to their use of current procedures. The Government sees the earnestness of this issue, and has quite recently begun creating methodologies to execute change $[7,8]$. 


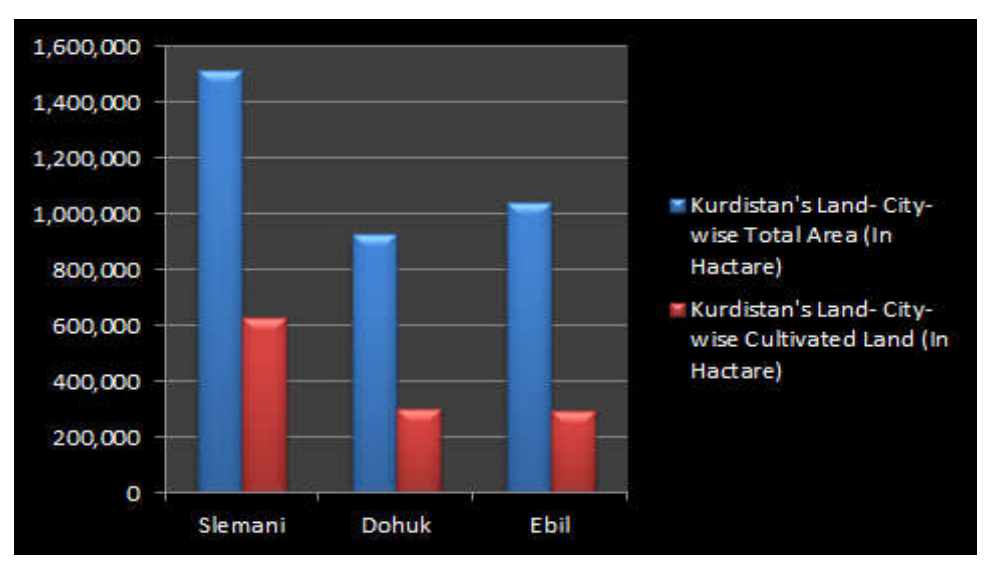

Figure 2 - Division of Kurdistan's Total land and cultivated land (source- KRG 2014)

Figure 2 shows that Kurdistan region's division of land, which is highly suited for agriculture as it boasts large areas of arable land and fertile soil.

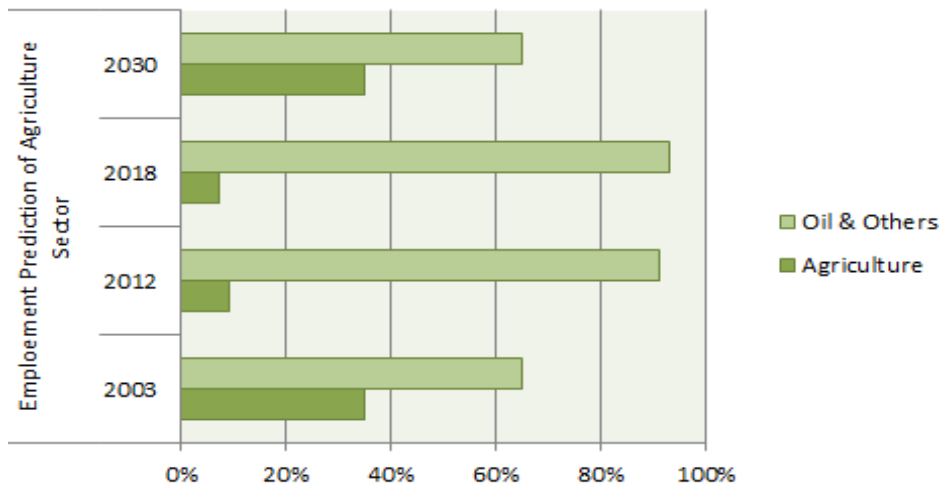

Figure 3 - Sector-wise employment trends (source- Ministry of KRG 2013)

Figure 3 shows that in 2003, around $35 \%$ of the quantity of occupants in the Kurdistan Region relied upon cultivating as their wellspring of occupation. In any case, by 2012, that rate had dropped to $9 \%$ due to nonappearance of fruitful methodologies. But after diversification picture of employment can be change by 2030.

Analysis of Primary Data (Structured Questionnaire):

Table 1 - Agriculture background of the respondents

\begin{tabular}{|c|c|c|c|c|c|}
\hline \multicolumn{2}{|c|}{ Are you from agriculture background? } & Frequency & Percent & Valid Percent & Cumulative Percent \\
\hline \multirow{3}{*}{ Valid } & Yes & 80 & 80 & 80 & 80 \\
\cline { 2 - 6 } & No & 20 & 20 & 20 & 100.0 \\
\cline { 2 - 6 } & Total & 100.0 & 100.0 & 100.0 & - \\
\hline
\end{tabular}

Farmer in the family of the respondents

\begin{tabular}{|c|c|c|c|c|c|}
\hline \multicolumn{2}{|c|}{ If yes, is there any farmer in your family? } & Frequency & Percent & Valid Percent & Cumulative Percent \\
\hline \multirow{3}{*}{ Valid } & Yes & 100 & 100 & 100 & 100.0 \\
\cline { 2 - 6 } & No & 0 & 0 & 0 & 100.0 \\
\cline { 2 - 6 } & Total & 100.0 & 100.0 & 100.0 & - \\
\hline
\end{tabular}

Agriculture field experience of the respondents

\begin{tabular}{|c|c|c|c|c|c|}
\hline \multicolumn{1}{|c|}{ If yes, for how many years you are in this sector? } & Frequency & Percent & Valid Percent & Cumulative Percent \\
\hline \multirow{4}{*}{ Valid } & $0-3$ Years & 12.5 & 12.5 & 12.5 & 12.5 \\
\cline { 2 - 6 } & $3-5$ Years & 30 & 30 & 30 & 42.5 \\
\cline { 2 - 6 } & 5-10 Years & 42.5 & 42.5 & 42.5 & 85.0 \\
\cline { 2 - 6 } & 10\&above & 15 & 15 & 15 & 100.0 \\
\cline { 2 - 6 } & Total & 100.0 & 100.0 & - \\
\hline
\end{tabular}


Table 2 - Agriculture role in economic development of the Kurdistan

\begin{tabular}{|c|c|c|c|c|c|}
\hline \multicolumn{2}{|c|}{$\begin{array}{c}\text { Do you think agriculture can play major role in economic } \\
\text { development of the Kurdistan }\end{array}$} & Frequency & Percent & $\begin{array}{c}\text { Valid } \\
\text { Percent }\end{array}$ & $\begin{array}{c}\text { Cumulative } \\
\text { Percent }\end{array}$ \\
\hline \multirow{3}{*}{ Valid } & Yes & 100 & 100 & 100 & 100.0 \\
\cline { 2 - 6 } & No & 0 & 0 & 0 & 100.0 \\
\hline & Total & 100.0 & 100.0 & 100.0 & \\
\hline
\end{tabular}

Major role is been played by the agriculture in the economic development

\begin{tabular}{|c|c|c|c|c|c|}
\hline \multicolumn{2}{|l|}{ If yes, what major role is been played by the agriculture in } & \multirow{2}{*}{$\begin{array}{c}\text { Frequency } \\
\text { the economic development: }\end{array}$} & Percent & $\begin{array}{c}\text { Valid } \\
\text { Percent }\end{array}$ & $\begin{array}{c}\text { Cumulative } \\
\text { Percent }\end{array}$ \\
\hline \multirow{4}{*}{ Valid } & Employment Generation & 6 & 6 & 6 & 6.0 \\
\cline { 2 - 6 } & Increase in GDP\& Government revenue & 6 & 6 & 6 & 12.0 \\
\cline { 2 - 6 } & Diversify development & 8 & 8 & 8 & 20.0 \\
\cline { 2 - 6 } & All of the above & 80 & 80 & 80 & 100.0 \\
\cline { 2 - 6 } & Total & 100.0 & 100.0 & 100.0 & - \\
\hline
\end{tabular}

Table 3 - Product of the respondents

\begin{tabular}{|c|c|c|c|c|c|}
\hline \multicolumn{2}{|c|}{ Do you produce more than one product? } & Frequency & Percent & Valid Percent & Cumulative Percent \\
\hline \multirow{3}{*}{ Valid } & Yes & 77.5 & 77.5 & 77.5 & 77.5 \\
\cline { 2 - 6 } & No & 22.5 & 22.5 & 22.5 & 100.0 \\
\cline { 2 - 6 } & Total & 100.0 & 100.0 & 100.0 & - \\
\hline
\end{tabular}

Types of products of the respondents

\begin{tabular}{|c|c|c|c|c|c|}
\hline \multicolumn{2}{|c|}{ If yes, which types of products you are producing: } & Frequency & Percent & Valid Percent & Cumulative Percent \\
\hline \multirow{4}{*}{ Valid } & Vegetables \& Fruits & 37.5 & 37.5 & 37.5 & 37.5 \\
\cline { 2 - 6 } & Millets/Wheat/Maze/Barley & 37.5 & 37.5 & 37.5 & 75.0 \\
\cline { 2 - 6 } & Poultry & 17.5 & 17.5 & 17.5 & 92.5 \\
\cline { 2 - 6 } & All of the above & 7.5 & 7.5 & 7.5 & 100.0 \\
\cline { 2 - 6 } & Total & 100.0 & 100.0 & 100.0 & \\
\hline
\end{tabular}

Table 4 - Government of Kurdistan helps in agriculture

\begin{tabular}{|c|c|c|c|c|c|}
\hline \multicolumn{2}{|c|}{$\begin{array}{c}\text { Does the Government of Kurdistan helps in } \\
\text { agriculture? }\end{array}$} & Frequency & Percent & $\begin{array}{c}\text { Valid } \\
\text { Percent }\end{array}$ & $\begin{array}{c}\text { Cumulative } \\
\text { Percent }\end{array}$ \\
\cline { 2 - 7 } & Yes & 75 & 75 & 75 & 75.0 \\
\cline { 2 - 7 } Valid & No & 25 & 25 & 25 & 100.0 \\
\hline & Total & 100.0 & 100.0 & 100.0 & - \\
\hline
\end{tabular}

Helping hand of the government

\begin{tabular}{|c|c|c|c|c|c|}
\hline \multicolumn{2}{|c|}{ If yes, what help you is getting? } & Frequency & Percent & Valid Percent & Cumulative Percent \\
\hline \multirow{4}{*}{ Valid } & Subsidy & 100.0 & 100.0 & 100.0 & 100.0 \\
\cline { 2 - 6 } & Technical & 0 & 0 & 0 & 0 \\
\cline { 2 - 6 } & Infrastructural & 0 & 0 & 0 & 0 \\
\cline { 2 - 6 } & Others & 0 & 0 & 0 & 100.0 \\
\cline { 2 - 6 } & Total & 100.0 & 100.0 & 100.0 & - \\
\hline
\end{tabular}

Table 5 - Government promote various crops according to climate conditions

\begin{tabular}{|c|c|c|c|c|c|}
\hline \multicolumn{2}{|c|}{$\begin{array}{c}\text { Does the Government of Kurdistan promote various target } \\
\text { crops according to climate conditions? }\end{array}$} & Frequency & Percent & $\begin{array}{c}\text { Valid } \\
\text { Percent }\end{array}$ & $\begin{array}{c}\text { Cumulative } \\
\text { Percent }\end{array}$ \\
\hline \multirow{3}{*}{ Valid } & Yes & 20 & 20 & 20 & 20 \\
\cline { 2 - 6 } & No & 80 & 80 & 80 & 100.0 \\
\cline { 2 - 6 } & Total & 100.0 & 100.0 & 100.0 & \\
\hline
\end{tabular}

Table 6 - Role of agriculture in the Kurdistan economy

\begin{tabular}{|c|c|c|c|c|c|}
\hline $\begin{array}{c}\text { Do you agree that in future the agriculture sector will play a } \\
\text { primary role in the Kurdistan economy? }\end{array}$ & Frequency & Percent & $\begin{array}{c}\text { Valid } \\
\text { Percent }\end{array}$ & $\begin{array}{c}\text { Cumulative } \\
\text { Percent }\end{array}$ \\
\hline \multirow{3}{*}{ Valid } & Yes & 100 & 100 & 100 & 100.0 \\
\cline { 2 - 6 } & No & 0 & 0 & 0 & 100.0 \\
\cline { 2 - 6 } & Total & 100.0 & 100.0 & 100.0 & - \\
\hline
\end{tabular}


Table 7 - Agriculture produce can satisfy the needs of the Kurdistan

\begin{tabular}{|c|c|c|c|c|c|}
\hline \multicolumn{2}{|c|}{$\begin{array}{l}\text { Do you think, through diversify development of Kurdistan in } \\
\text { future; the agriculture produce can satisfy the needs of the } \\
\text { Kurdistan in Total? }\end{array}$} & Frequency & Percent & $\begin{array}{c}\text { Valid } \\
\text { Percent }\end{array}$ & $\begin{array}{c}\text { Cumulative } \\
\text { Percent }\end{array}$ \\
\hline \multirow{3}{*}{ Valid } & Yes & 100 & 100 & 100 & 100.0 \\
\cline { 2 - 6 } & No & 0 & 0 & 0 & 100.0 \\
\cline { 2 - 6 } & Total & 100.0 & 100.0 & 100.0 & \\
\hline
\end{tabular}

Table 8 - FDI in agriculture can increase GDP through agro-technologyl

\begin{tabular}{|c|c|c|c|c|c|}
\hline \multicolumn{2}{|c|}{$\begin{array}{c}\text { Do you agree that FDI in agriculture can increase GDP } \\
\text { through agro-technology? }\end{array}$} & Frequency & Percent & $\begin{array}{c}\text { Valid } \\
\text { Percent }\end{array}$ & $\begin{array}{c}\text { Cumulative } \\
\text { Percent }\end{array}$ \\
\hline Valid & Yes & 84 & 84 & 84 & 84 \\
\hline & No & 16 & 16 & 16 & 100.0 \\
\hline
\end{tabular}

Table 9 - Insurance eliminates the risk in agriculture and promotes for further export

\begin{tabular}{|c|c|c|c|c|c|}
\hline \multicolumn{2}{|l|}{$\begin{array}{c}\text { If Insurance is provided, do you think it eliminates the risk in } \\
\text { agriculture and promotes for further export of your products? }\end{array}$} & Frequency & Percent & $\begin{array}{c}\text { Valid } \\
\text { Percent }\end{array}$ & $\begin{array}{c}\text { Cumulative } \\
\text { Percent }\end{array}$ \\
\hline \multirow{2}{*}{ Valid } & Yes & 100 & 100 & 100 & 100.0 \\
\cline { 2 - 6 } & No & 0 & 0 & 0 & 100.0 \\
\cline { 2 - 6 } & Total & 100.0 & 100.0 & 100.0 & - \\
\hline
\end{tabular}

Table 1 describes about the agriculture background of the respondents where the majority of $80 \%$ are from the same. Out of the $80 \%$ of respondents all are the farmers. As mentioned, finding shows that $42.5 \%$ respondents have more than $5-10$ years of experience in agriculture.

Table 2 shows that all the respondents have agreed that Agriculture can play the major role in the economic development of Kurdistan in future as an employment generation, increase in GDP, Increase in Government revenue and diversify development.

From the table 3 , it is found that only $22.5 \%$ respondents' produce one product and the rest concentrate on more than one product, where vegetables and fruits and millets plays a vital role of $75.0 \%$ of cumulative percentage, and a minimum of $17.5 \%$ are producing poultry.

From the table 4 , it is inferred that majority of $75 \%$ are getting help from the government of Kurdistan as subsidies.

According to the table 5, instead of helping the farmers by giving subsidies, majority of $80 \%$ of respondents feel that the govt. does not promote for various crops according to the climate conditions

Table 6 shows the respondents who have totally agreed that the Agri-sector will play a primary role in future and it can satisfy the total needs of Kurdistan, according to the respondents (Table 7).

From the table 8, it is found that all respondents have agreed that the FDI in agriculture can increase the GDP through the use of Agro-technology.

Finally, all the respondents were totally agreed that if insurance would be provided it can eliminate all the risk and also promote the products for exporting (Table 9).

To make the $20 \%$ of the respondents (table 3 ) to produce more than one diversified products, the govt. of Kurdistan has to concentrate them by providing more information regarding the necessity of the produce and by giving more financial assistance.

- Measures to be taken for the increase of production in farming of poultry as only $17.5 \%$ of the farmers who are indulged in it;

- To concentrate on the $25 \%$ of the respondents who are not aware of the govt. help in agriculture, the government has to conduct awareness programs regarding their support;

- For the $16 \%$ of the respondents who do not believe in FDI in agriculture could increase the GDP through agro-technology, the government of Kurdistan can 
motivate the farmers in neglecting the information by providing insurance as it eliminates the risk in production.

Proposed models:

Agriculture Finance and Insurance Scheme for Farmers \& FDI Small Investor Scheme for Agriculture Export. Planning Department of ministry should take the feedback of existing agriculture schemes through its Feedback mechanism assessment system, because these existing schemes are not effective in long run. So, Instead of existing scheme government can implement my proposed model of agriculture finance \& Insurance scheme for crop production with some modification according to their needs.

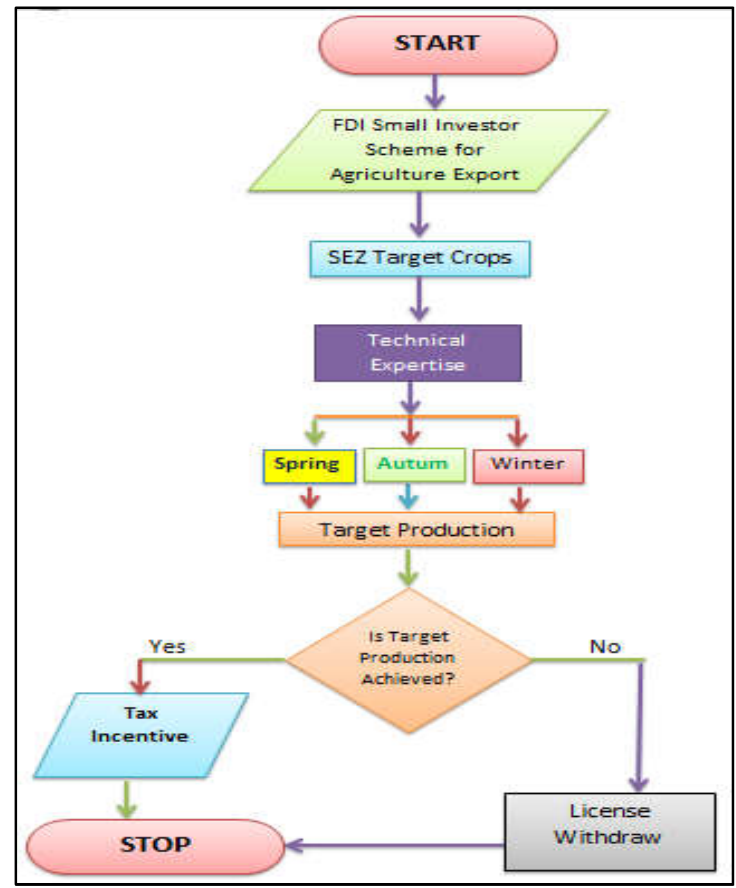

Figure 4 - Agriculture Finance and Insurance Scheme (Source- Primary Data)

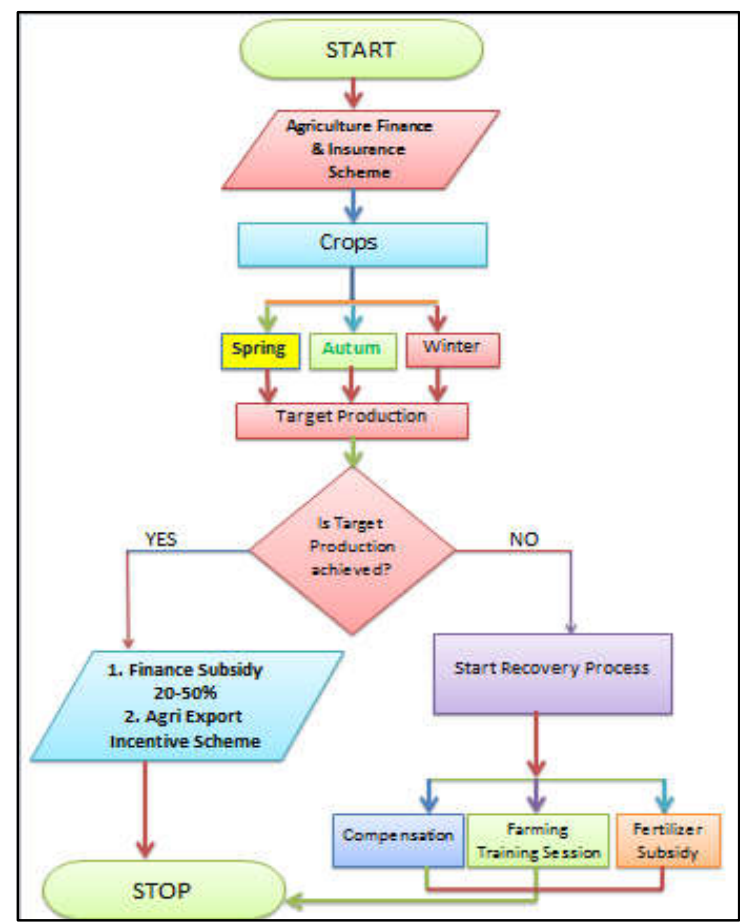

Figure 5 - FDI Small Investor Scheme for Agriculture Export (Source- Primary Data) 
For execution of this model, Government has to set-up a special group for implementing this scheme. Figure 4 shows; first the special group team is required in making this scheme according to the needs for all the climates. Secondly, as this scheme is a target based, they have to set the target crops under this scheme, in which the farmers can achieve a higher growth.

If the target production is achieved then this model would provide the following:

- Finance subsidy of (20-50\%) subject to change;

- If the producer will export the target crops then this scheme will also provide export incentive from 2-5\% (subject to change).

If the target production is not achieved then this scheme will not provide the above benefit but another recovery process can start for motivation of farmers, this process will provide:

- Risk cover includes compensation for farmer from indebtness;

- Fertilizer subsidy for next season crops;

- Special farming training season could be organized for the farmers in next season crop.

Model in Figure 5 is specifically targeting to small foreign investors, who have the core technical expertise in targeting crops production according to climate. This system can help to the government for making foreign investment policy with special reference to targeting agriculture growth.

This model is targeted for small investor in SEZ area. In the special economic zone, firstly, the crops should be targeted for which the higher growth is required. Corporate firms should give the responsibility for achieving targeted planned growth and pooling of all the investment is also needed for creating infrastructure in SEZ. For pooling of investment resources, FDI participation should be invited from small investor via FDI Small Investor Scheme. Investments which are generated through FDI scheme include money, technical expertise, skills. This Investment model can help in achieving the targeted production. According to the model, if the said investor will achieve the target then they can get benefitted from local tax incentive as well as from the export incentives. If the target is not achieved then license may be withdrawn.

\section{CONCLUSION}

Currently, the Kurdistan region is facing financial crisis is due to the economic dependence on oil sector. The government of this region is financially depending on Iraq federal budget allocation to Kurdistan. From 2014, the fluctuation in oil prices and terrorism threats did affect the revenue of government. Insufficiency of budget did stop the crucial development projects of this area. At present, Agriculture sector contribution to GDP is only $10 \%$, but this sector has the potential to grow very fast. This is notable that this sector has the potential to become the primary sector in mere future. Even the regional government has made the policies to make it possible but due to inadequacy of fund and technology constraints are the major problem for achieving it. Diversification of oil economy to agriculture needs some more efforts for planned Investment policies. If these proposed models are adopted with some modifications according to needs then, this sector can drastically change the picture of Kurdistan economy.

\section{REFERENCES}

1. KRG "Kurdistan's geography and climate"; http://cabinet.gov.krd/p/page.aspx?l= $12 \& s=050000 \& r=303 \& p=213$ accessed on $10 / 10 / 2018$

2. Baban, S. (2015) "Revitalizing Agriculture and Water Sectors in the Kurdistan Region, Iraq", Athens: ATINER'S Conference Paper Series, No: GEO2015-1618. https://www.mdpi.com/2073-445X/6/2/44 accessed on 15/10/2018

3. Lina Eklund, Abdulhakim Abdi and Mine Islar (2017). "From Producers to Consumers: The Challenges and Opportunities of Agricultural Development in Iraqi Kurdistan" 
https://www.researchgate.net/publication/283441920_Revitalising_Agriculture_and_Wate r_Sectors_in_the_Kurdistan_Region_Iraq accessed on 07/10/2018

4. Ábdulmuttaleb Abbas SALIH, Hussein Ali Hussein AL-QAESI (2018). "The perspective of agricultural development in Iraq" http://managementjournal.usamv.ro/ pdf/vol.18_1/Art54.pdf accessed on 07/10/2018

5. Ugo Fasano 2/ UNFCCC Workshop (2003). Diversification in oil-dependent economies: The experience of the GCC countries. https://unfccc.int/sites/default/files/ 200311_ed_imf.pdf accessed on 07/10/2018

6. World Bank Report (2011). The Kurdistan region of Iraq "Assessing the economic and social impact of Syrian conflict and ISIS"; http://documents.worldbank.org/ curated/en/579451468305943474/pdf/958080PUB0ApriOPUBLIC09781464805486.pdf accessed on $07 / 10 / 2018$

Anaid. Anwar (2016). The Future Economic Challenges of Kurdistan; http://investingroup.org/analysis/249/the-future-economic-challenges-of-kurdistankurdistan/ accessed on 07/01/2019

7. Invest in Group (2013). Restoring the Bread Basket: Agriculture; http://investingroup.org/review/240/restoring-the-bread-basket-agriculture-kurdistan/ accessed on 07/01/2019

8. Tinti A. (2017). Water Resources Management in the Kurdistan Region of Iraq; https://auis.edu.krd/iris/sites/default/files/Water\%20Policy\%20Report\%20IRIS_FINAL\%2 OES.pdf

9. Rudaw (2017). Kurdistan is largely self-sufficient, agriculture minister reassures population; http://www.rudaw.net/english/kurdistan/070820172 